Article

\title{
Antibacterial Silicon Oxide Thin Films Doped with Zinc and Copper Grown by Atmospheric Pressure Plasma Chemical Vapor Deposition
}

\author{
Elisabeth Jäger ${ }^{1,2}$, Jürgen Schmidt ${ }^{2}$, Andreas Pfuch ${ }^{2}$, Sebastian Spange ${ }^{2}$, Oliver Beier ${ }^{2}$, \\ Nikolaus Jäger ${ }^{1}$, Oliver Jantschner ${ }^{1}$, Rostislav Daniel ${ }^{1}$ and Christian Mitterer ${ }^{1, *(D)}$ \\ 1 Department of Materials Science, Montanuniversität Leoben, Franz-Josef-Straße 18, 8700 Leoben, Austria; \\ Elisabeth.Jaeger@stud.unileoben.ac.at (E.J.); Nikolaus.Jaeger@unileoben.ac.at (N.J.); \\ Oliver.Jantschner@stud.unileoben.ac.at (O.J.); Rostislav.Daniel@unileoben.ac.at (R.D.) \\ 2 INNOVENT e.V. Technology Development Jena, Prüssingstraße 27B, 07745 Jena, Germany; \\ js@innovent-jena.de (J.S.); ap@innovent-jena.de (A.P.); ss@innovent-jena.de (S.S.); \\ ob@innovent-jena.de (O.B.) \\ * Correspondence: Christian.Mitterer@unileoben.ac.at; Tel.: +43-3842-402-4220
}

Received: 2 January 2019; Accepted: 11 February 2019; Published: 13 February 2019

\begin{abstract}
Zn}$-doped and $\mathrm{Cu}$-doped $\mathrm{SiO}_{\mathrm{x}}$ films were synthesized by atmospheric pressure plasma chemical vapor deposition to study their antibacterial efficiency against Gram-negative Escherichia coli and their cytotoxic effect on the growth of mouse cells. Zn-rich and Cu-rich particles with diameters up to several microns were found to be homogeneously distributed within the $\mathrm{SiO}_{\mathrm{x}}$ films. For both doping elements, bacteria are killed within the first three hours after exposure to the film surface. In contrast, mouse cells grow well on the surfaces of both film types, with a slight inhibition present only after the first day of exposure. The obtained results indicate that the films show a high potential for use as effective antibacterial surfaces for medical applications.
\end{abstract}

Keywords: thin films; silicon oxide; copper; zinc; antibacterial films

\section{Introduction}

Medical implants like surgical nails, screws, and plates are commonly used to immobilize fractured human bone to ensure a successful healing process. If any part of the healing sequence is altered by micro-organisms [1], the healing process may be extended dramatically. According to References [2,3], the prevalence rate of hospital-acquired infections by the colonization of the surfaces of medical implants or surgical instruments with bacteria within the Western world varies between $4 \%$ and $10 \%$, with peak values up to $30 \%$ in intense care units. One possible solution to protect the patient from infection, sepsis, and putrefaction is to coat the implant with films containing antiseptic elements like $\mathrm{Ag}, \mathrm{Zn}$, or $\mathrm{Cu}$. While these metals are well known for their antibacterial efficiency [4], medical implants and surgical instruments require multi-functional surfaces with the necessary additional wear-resistance and bio-compatibility. Thus, advanced antibacterial thin films are often based on a nanocomposite approach where the antibacterial agent is combined with a robust and inert ceramic matrix [5]. The antibacterial agent permanently needs to be available at the point of action, i.e., on the surface of an implant or instrument. This pre-condition could be met either by the immediate availability of antibacterial agents on the surface of the inert matrix or by the continuing release during its mechanical wear.

There is a plethora of published reports regarding the design and synthesis of thin films containing antibacterial agents (see References [3,5] for recent reviews). Additionally, numerous deposition techniques like atmospheric pressure plasma chemical vapor deposition (APCVD), combustion 
chemical vapor deposition [6], physical vapor deposition [7,8], and electrodeposition [9] have been used to deposit such antibacterial films. Recently, novel antimicrobial nanocomposites, e.g., based on halloysite nanotubes and $\mathrm{Ag}$ and $\mathrm{ZnO}$ nanoparticles [10], flax fibers with $\mathrm{Ag}$ and $\mathrm{ZnO}$ nanoparticles [11], or cellulose with Ag nanoparticles [12] have been suggested. A drawback of some of the used synthesis techniques is that they are based on the use of harmful and toxic chemicals [13], that they are not suitable to realize the required nanocomposite architecture necessary for multi-functional surfaces or that they are vacuum-based techniques resulting in high efforts and costs for production [14].

The efficiency of $\mathrm{Ag}$ as an antibacterial agent in the form of nanoparticles is extensively described in literature $[13,15,16]$. Ag may be used as antibacterial material in the form of salts, dendrimers, polymers, and metal oxide nanoparticles, and then impregnated zeolites and activated carbon materials $[15,16]$. The antibacterial efficiency of Ag nanoparticles is determined by the release of Ag ions, which are assumed to damage bacterial cell walls $[15,16]$. However, an essential drawback of $\mathrm{Ag}$ is that it is not inherently present in the human body, which necessitates some caution in its application [16].

Thus, the aim of this study is to synthesize multi-functional thin films based on a robust and bio-compatible silicon oxide $\left(\mathrm{SiO}_{\mathrm{x}}\right)$ matrix doped with the antiseptic elements $\mathrm{Zn}$ and $\mathrm{Cu}$ (both being trace elements in the human body) using the environmentally-friendly APCVD technique. The synthesized films are expected to provide significant antimicrobial effects against Gram-negative Escherichia coli (E. coli) and, otherwise, to ensure sufficient growth and vitality of osteoblastic mouse cells. The chemical structure and composition, the antibacterial effect, and cell growth were studied, as well as the influence of sterilization and washing procedures, with the aim to provide the first results for an optimization of the $\mathrm{Zn}$ and $\mathrm{Cu}$ content.

\section{Materials and Methods}

APCVD combining a typical CVD process with a plasma discharge at atmospheric pressure was used to deposit the films. As substrates, pre-cleaned (isopropanol) polished B-doped 525- $\mu \mathrm{m}$-thick Si(100) strips $\left(10 \times 20 \mathrm{~mm}^{2}\right)$ as well as disks of size $\phi 15 \times 3 \mathrm{~mm}$ made of a titanium alloy of type TiAl6V4 (arithmetic surface roughness $R_{a}=515 \pm 68 \mathrm{~nm}$ ) and austenitic stainless steel (X2 CrNiMo 18153 , DIN 1.4441, $R_{a}=476 \pm 105 \mathrm{~nm}$ ), both supplied by Königsee Implantate, Allendorf, Germany, were used for deposition of $\mathrm{Zn}$-doped and $\mathrm{Cu}$-doped $\mathrm{SiO}_{\mathrm{x}}$ films (in the following denominated as $\mathrm{Zn}-\mathrm{SiO}_{\mathrm{x}}$ and $\mathrm{Cu}-\mathrm{SiO}_{\mathrm{x}}$ films, respectively). As a primary precursor, evaporated hexamethyldisiloxane (HMDSO) was used to create the $\mathrm{SiO}_{\mathrm{x}}$ thin film matrix. The HMDSO molecules were dissociated in the plasma discharge, mainly by collisional processes with oxygen and nitrogen molecules in the deposition chamber. The film is subsequently formed by $\mathrm{SiO}_{\mathrm{x}}$ particles originating from reactions of the dissociated primary precursor with oxygen [17]. Besides the primary gaseous HMDSO precursor, solutions with zinc nitrate $\mathrm{Zn}\left(\mathrm{NO}_{3}\right)_{2}$ and copper nitrate $\mathrm{Cu}\left(\mathrm{NO}_{3}\right)_{2}$, both in a 1:1 volume mixture of isopropanol and water, were sprayed into the plasma as secondary precursors. The dissociation of the precursor molecules allowed reactions of $\mathrm{Zn}$ and $\mathrm{Cu}$ with oxygen and, consequently, formation of $\mathrm{ZnO}_{x}$ and $\mathrm{CuO}_{x}$ particles, respectively, which are subsequently incorporated into the $\mathrm{SiO}_{x}$ film. The variable parameters used to adjust the $\mathrm{Zn}$ and $\mathrm{Cu}$ content in the films were the flow rates of the $\mathrm{Zn}\left(\mathrm{NO}_{3}\right)_{2}$ and $\mathrm{Cu}\left(\mathrm{NO}_{3}\right)_{2}$ solutions, respectively, as summarized in Table 1.

Table 1. Secondary precursor conditions used for the APCVD process.

\begin{tabular}{ccc}
\hline Secondary Precursor & $\mathbf{Z n}\left(\mathbf{N O}_{3}\right)_{\mathbf{2}}$ & $\mathbf{C u}\left(\mathrm{NO}_{\mathbf{3}}\right)_{\mathbf{2}}$ \\
\hline Concentration [wt. $\%$ ] & 5 & 2.5 \\
Isopropanol:water volume ratio & $1: 1$ & $1: 1$ \\
Flow rate $[\mu \mathrm{L} / \mathrm{min}]$ & $25 ; 50 ; 100$ & $12.5 ; 25 ; 50$ \\
\hline
\end{tabular}


As the plasma source for the APCVD process, a plasma jet of type BLASTER MEF (TIGRES, Marschacht, Germany) was used in combination with a modified plasma blast pipe, which enables it to feed additives as second precursors into the plasma. A mid-frequency $(\sim 40 \mathrm{kHz})$ pulsed dc plasma was ignited between two cylindrical electrodes, i.e., an inner stick electrode and the actual plasma nozzle as the grounded outer electrode. The plasma jet was accelerated using compressed air at a pressure of 6 bar. The length of the plasma jet was controlled by the applied power set to $400 \mathrm{~W}$. Further details on the APCVD process are reported in previous papers $[6,17,18]$. The substrates were located at a distance of $10 \mathrm{~mm}$ below the plasma jet. All samples were moved in meandering patterns with respect to the stationary plasma jet, with a set grid spacing distance of $3 \mathrm{~mm}$. To achieve a film thickness of $\sim 100 \mathrm{~nm}$, 8 runs during the deposition process were realized.

While the silicon substrates were used for film characterization by scanning electron microscopy (SEM), energy dispersive X-ray spectroscopy (EDX), atomic force microscopy (AFM), and X-ray photoelectron spectroscopy (XPS), the TiAl6V4 and the austenitic stainless steel disks were used for the application-oriented tests. In this case, TiAl6V4 represents a typical implant material, while austenitic stainless steels are widely used for surgery instruments. Both film thickness and arithmetic surface roughness $R_{a}$ were measured using a stylus contact profilometer (Dektak $3 \mathrm{ST}$ ). The film surface was investigated using a Carl Zeiss SUPRA 55 VP SEM using acceleration voltages of 5 and $15 \mathrm{kV}$ and working distances of 4.4 and $10.4 \mathrm{~mm}$. The size distribution of particles formed on the film surface and visible in the SEM micrographs was statistically analyzed by the free software ImageJ [19]. In addition, the surface topography of the films was characterized using a SIS ULTRAObjective AFM in the non-contact mode. EDX (Quantax with $\mathrm{Si}(\mathrm{Li})$-detector, Röntec) and XPS (Theta Probe, Thermo VG Scientific) determined the chemical composition of the films. The oxidation states of $\mathrm{Zn}, \mathrm{Cu}$, and $\mathrm{Si}$ were identified by XPS using an X-ray excitation energy of $1468.68 \mathrm{eV}$ ( $\mathrm{Al} \mathrm{K} \alpha$ line). The $2 \mathrm{p}$ core level spectra were used for determining the respective metal oxides. No thermal treatment or sputter cleaning of the surfaces was done prior to the XPS measurements. As energy calibration, the binding energy of the $C 1$ s level $(285 \mathrm{eV})$, taken from the carbon contamination, was used. To probe the resistance of the films against abrasive wear and, consequentially, to evaluate the residual antiseptic effect of the films, a washability test (Elcometer, Simex) in distilled water was performed using nylon brushes and a stainless steel holder, according to the ASTM D2486 standard. The number of washing cycles varied from 1000 to 10,000 .

The fluorescein diacetate/GelRed live/dead staining assay was used to study the cytotoxic effect of the films on osteoblastic mouse cells of type MC 3T3-E1. The cells were cultured at $37{ }^{\circ} \mathrm{C}$ under $5 \% \mathrm{CO}_{2}$ atmosphere in Dulbecco's modified Eagle's medium with $10 \%$ fetal calf serum, which was supplemented with $50 \mathrm{U} / \mathrm{mL}$ penicillin and $50 \mu \mathrm{g} / \mathrm{mL}$ streptomycin (Biochrom, Berlin, Germany). For the test, the cells were brought into direct contact with the film surface in a density of $\sim 12,500$ cells $/ \mathrm{cm}^{2}$. After one, three, and seven days of incubation, the live/dead staining assay was performed. The cell coloration micrographs were taken using a Carl Zeiss Axiotech fluorescence microscope.

The antibacterial effect of the films was probed using a Gram-negative E. coli strain. The BacTiter-Glo microbial cell assay (BTG, Promega, Mannheim, Germany) was used to detect bacterial injury on the basis of the intracellular adenosine triphosphate (ATP) content of the cells. For the test, E. coli bacteria were brought into direct contact with the film surface. Each sample was immersed in $0.5 \mathrm{~mL}$ of the diluted E. coli working suspension for $3 \mathrm{~h}$. The developed luminescence signals were recorded in a microplate reader (Genios Pro, Tecan), which enables luminescence detection using an integration time of $400 \mathrm{~ms}$. An antibacterial effect was detected if the BTG test showed a decrease of luminescence in comparison to the unaffected control samples.

Sterilization tests were done under hospital cleaning and sterilization conditions (Thüringen-Kliniken "Georgius Agricola", Germany) to evaluate the antibacterial effect of the films after such treatments. The cleaning step over $50 \mathrm{~min}$ was realized by a cleaning, disinfection, and drying machine (Belimed WD380) with a washing temperature of $93^{\circ} \mathrm{C}$ and a drying temperature of 
$110^{\circ} \mathrm{C}$. The subsequent sterilization step of $5 \mathrm{~min}$ was performed by using a steam-sterilizer (MMM Selectomat), where the temperature ranged from 134 to $137^{\circ} \mathrm{C}$ and the pressure was between 3034 and 3320 mbar. Subsequently, the BTG test was performed on the film surface.

\section{Results}

\subsection{Film Morphology and Chemical Composition}

All films were optically transparent and showed no evidence of delamination. For the $\mathrm{Zn}-\mathrm{SiO}$ films, the series of SEM surface topology micrographs presented in Figure 1 show that only a low number of small particles is visible on the surface of $\mathrm{SiO}_{x}$ films deposited without a secondary precursor, whereas both the density and size of these particles increase significantly for the increasing secondary precursor flow rate. The SEM micrograph and the Zn elemental map obtained by EDX depicted in Figure 2 clearly indicate that the micron-sized particles visible in Figure $1 \mathrm{~b}-\mathrm{d}$ are rich in Zn. Besides these Zn-rich particles, a lower Zn concentration was detected to be homogeneously distributed throughout the film.
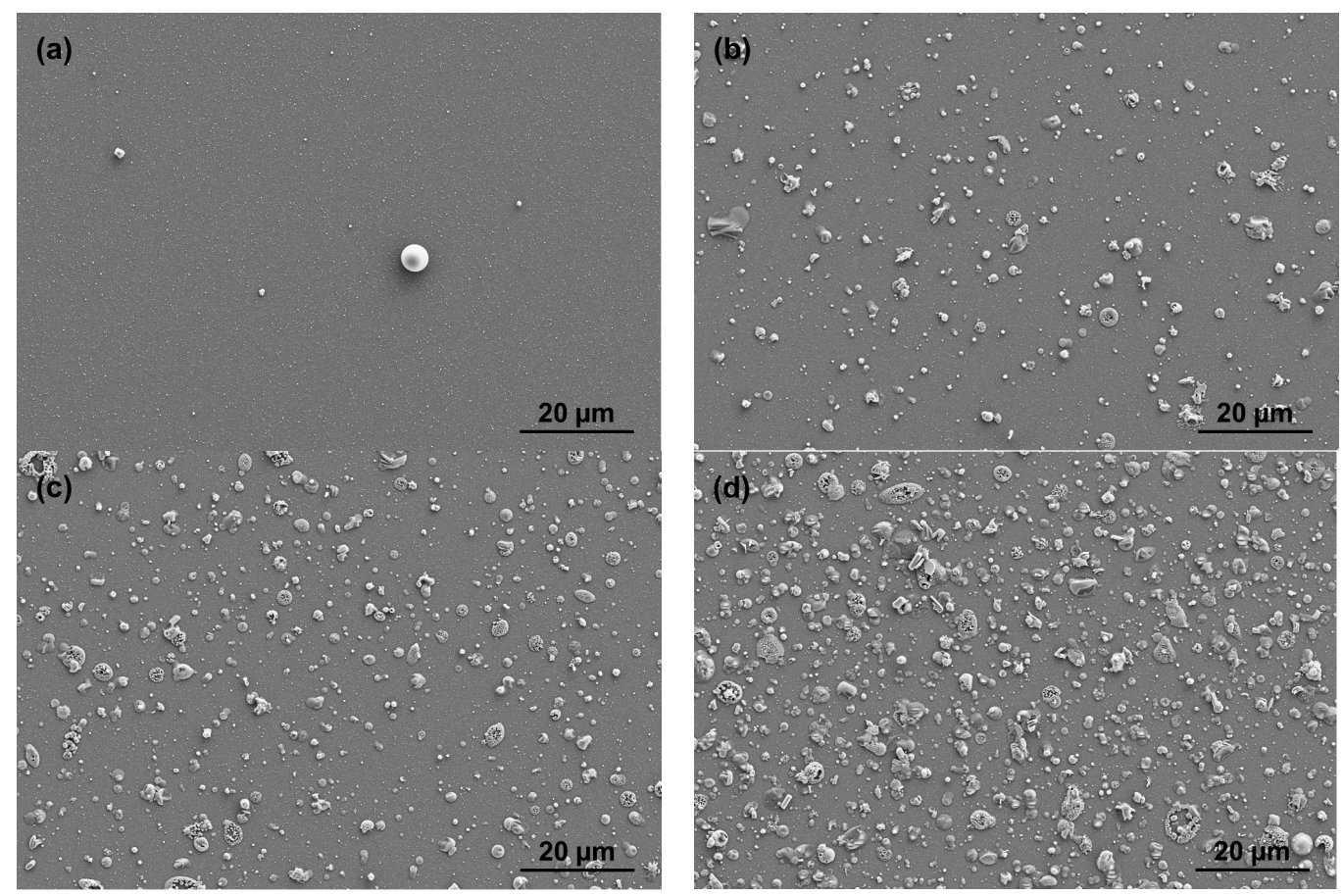

Figure 1. SEM micrographs of the surface topography of $\mathrm{Zn}-\mathrm{SiO}_{\mathrm{x}}$ films grown on Si with secondary precursor flow rates of (a) 0 , (b) 25 , (c) 50 , and (d) $100 \mu \mathrm{L} / \mathrm{min}$.
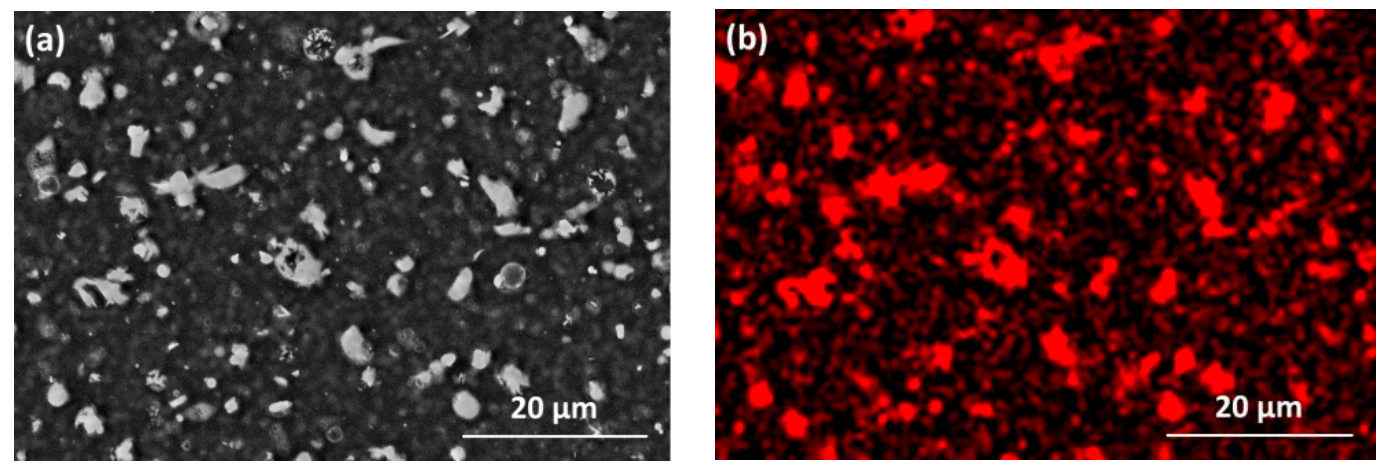

Figure 2. (a) SEM micrograph of the surface topography and (b) the corresponding Zn EDX mapping for a $\mathrm{Zn}-\mathrm{SiO}_{\mathrm{x}}$ film grown on $\mathrm{Si}$ with a secondary precursor flow rate of $100 \mu \mathrm{L} / \mathrm{min}$. 
Both austenitic stainless steel and TiAl6V4 substrates coated with $\mathrm{Zn}-\mathrm{SiO}_{\mathrm{x}}$ and $\mathrm{Cu}-\mathrm{SiO}$ films exhibit a surface roughness $\mathrm{R}_{\mathrm{a}}$ determined using a stylus contact profilometer in the range of 480 to $1120 \mathrm{~nm}$. The upper values have been obtained for high flow rates of the secondary precursor (see Table 1 and Figure 1) and they are considerably higher than those of the uncoated reference samples (see Section 2) or for samples coated with a pure $\mathrm{SiO}_{\mathrm{x}}$ film $\left(\mathrm{R}_{\mathrm{a}}=340-540 \mathrm{~nm}\right)$. They also significantly exceed the film thickness of $\sim 100 \mathrm{~nm}$. This is attributed to the formation of the particles visible in Figures 1 and 2. Figure 3 represents a series of AFM surface topography images of $\mathrm{Zn}-\mathrm{SiO}$ films deposited at different flow rates of the secondary precursor, which shows that the un-doped $\mathrm{SiO}_{\mathrm{x}}$ film is quite smooth, whereas major particles in the $\mathrm{Zn}-\mathrm{SiO}_{\mathbf{x}}$ films protrude up to $1 \mu \mathrm{m}$ above the film surface.
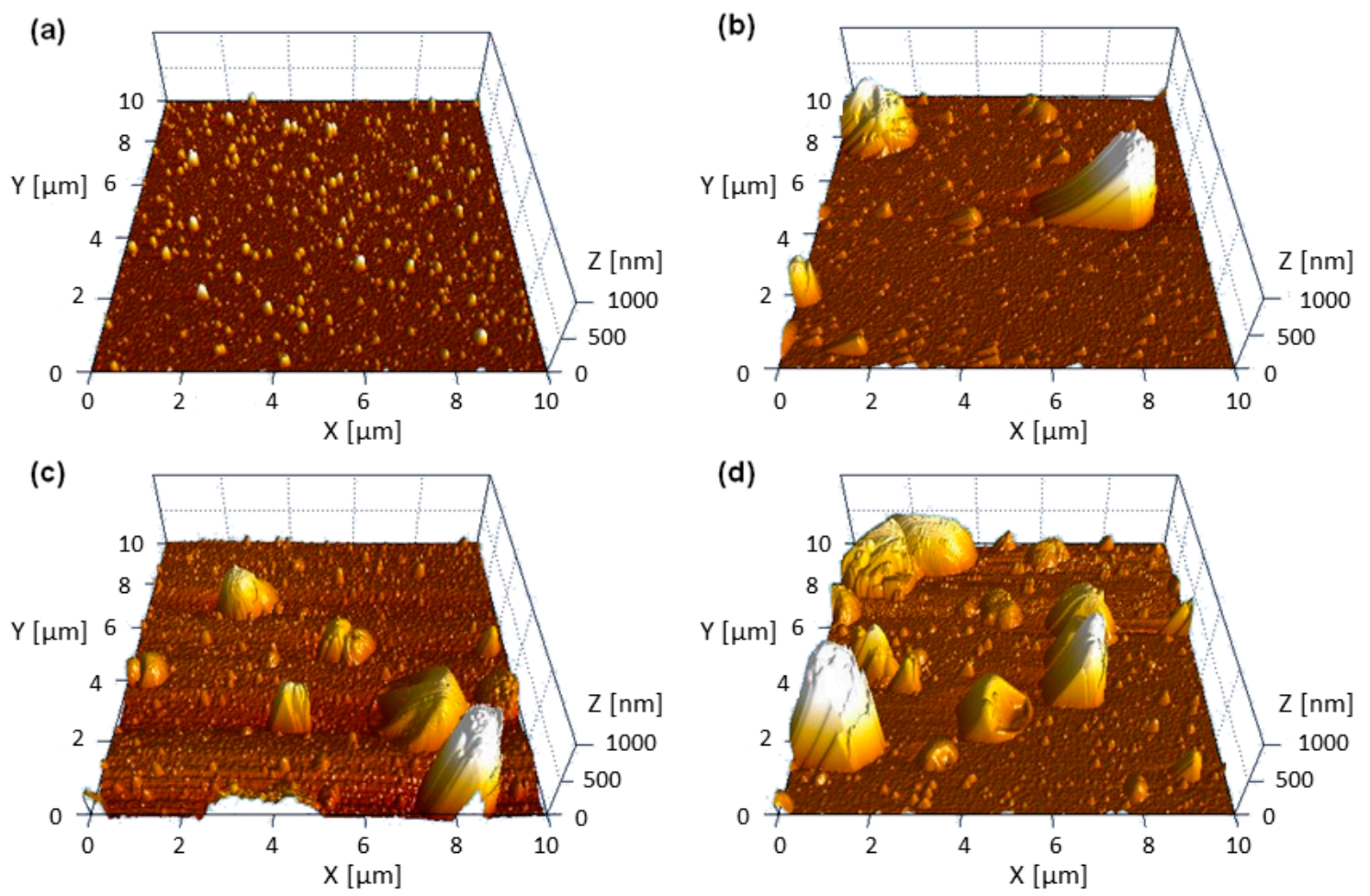

Figure 3. AFM surface topography images of $\mathrm{Zn}-\mathrm{SiO}_{\mathrm{x}}$ films grown on $\mathrm{Si}$ with secondary precursor flow rates of (a) 0 , (b) 25 , (c) 50 , and (d) $100 \mu \mathrm{L} / \mathrm{min}$.

The particle size distribution on the surface of $\mathrm{Zn}-\mathrm{SiO}_{\mathrm{x}}$ films grown on $\mathrm{Si}$ was statistically analyzed using the SEM micrographs presented in Figure 1. Figure 4 indicates that the vast majority of particles visible on the surface of an un-doped $\mathrm{SiO}_{x}$ film occupies an area of less than $2 \mu \mathrm{m}^{2}$. A more detailed analysis and Figure 3a show a particle diameter of up to 200 to $300 \mathrm{~nm}$. In contrast, these small particles characteristic for the un-doped $\mathrm{SiO}_{\mathrm{x}}$ film are still present for an increasing flow rate of the secondary precursor, whereas the fraction of larger and, according to Figure 2b, Zn-rich particles increases considerably. The maximum particle size observed on $\mathrm{Zn}-\mathrm{SiO}_{\mathrm{x}}$ films increases from 12 to $14 \mu \mathrm{m}^{2}$ (corresponding to a diameter of 3.9 to $4.2 \mu \mathrm{m}$ of an equivalent circular particle) to $22-24 \mu \mathrm{m}^{2}$ (5.3-5.5 $\mu \mathrm{m}$ diameter) for increasing secondary precursor flow rates (see Figure 4).

The formation of slightly smaller and less frequently appearing $\mathrm{Cu}$-rich particles on the surface of the $\mathrm{Cu}-\mathrm{SiO}_{\mathrm{x}}$ films indicates the same growth mechanism of the particles such as in the case of $\mathrm{Zn}-\mathrm{SiO}$. The formation of these particles corresponds well to earlier findings on $\mathrm{SiO}_{\mathrm{x}}$ film with embedded $\mathrm{Ag}$ particles grown by APCVD [16]. To sum up, all formed films can be described as composites with Zn-rich or Cu-rich particles, which are characterized by a diameter range of up to several microns and embedded into a $\mathrm{SiO}_{x}$ film formed by particles of up to 200-300 $\mathrm{nm}$ in diameter. 


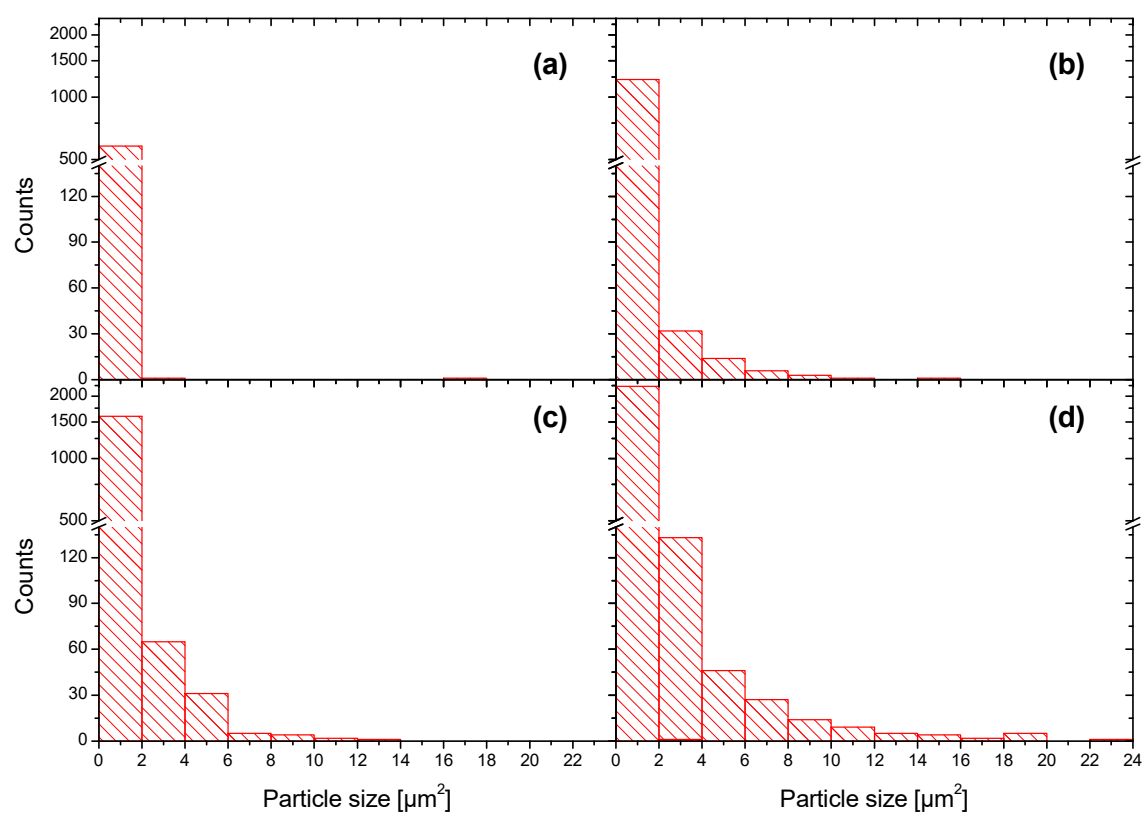

Figure 4. Particle size distribution determined by statistical analysis using the SEM micrographs shown

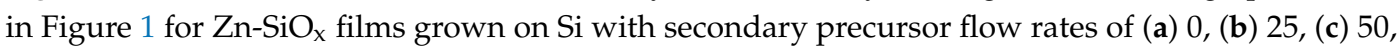
and (d) $100 \mu \mathrm{L} / \mathrm{min}$.

Figure 5 shows the XPS spectra of the $\mathrm{Zn}-\mathrm{SiO}_{\mathrm{x}}$ film grown at the highest flow rate of the secondary precursor of $100 \mu \mathrm{L} / \mathrm{min}$. Peak fit analysis was used to separate the spectra into individual components. The peaks in the Si 2p spectrum shown in Figure 5a located at 103.9 and $102.2 \mathrm{eV}$ correspond to Si-O and $\mathrm{Si}-\mathrm{N}$ bonds, respectively, which is in good agreement with literature [20]. The $\mathrm{Si}-\mathrm{N}$ bonds originate from the small amount of nitrogen incorporated in the films from fractions that are not fully dissipated as a secondary precursor. The two peak positions in the $\mathrm{O} 1 \mathrm{~s}$ spectrum in Figure $5 \mathrm{~b}$ located at 533.3 and $531.5 \mathrm{eV}$ correspond to $\mathrm{O}-\mathrm{Si}$ and $\mathrm{O}-\mathrm{Zn}$ bonds, which agree well with the $\mathrm{Si}-\mathrm{O}$ bonds at $103.0 \mathrm{eV}$ in Figure $5 \mathrm{a}$ and the $\mathrm{Zn}-\mathrm{O}$ bonds at $1021.7 \mathrm{eV}$ in Figure 5c. The observed binding energies of $531.5 \mathrm{eV}$ and $1021.7 \mathrm{eV}$ correspond well to those reported for stoichiometric $\mathrm{ZnO}$ nanoparticles [21], which indicate a composition close to $\mathrm{ZnO}$ for the particles incorporated in the $\mathrm{Zn}-\mathrm{SiO}_{\mathrm{x}}$ films. In addition, the absence of Si-Si and $\mathrm{Zn}-\mathrm{Zn}$ bonds in the surface near the region indicates full oxidation of the film species (besides the minor nitride fraction mentioned above), which is due to the much higher enthalpy of formation of the oxide components with respect to the metallic bonding [20]. The $C 1$ s spectrum in Figure $5 \mathrm{~d}$ indicates carbon surface contamination at $284.5 \mathrm{eV}$, with the additional peaks between 286 and $290 \mathrm{eV}$ identified as $\mathrm{C}$ and $\mathrm{O}$ containing species. Minor bulk carbon contaminations, as visible by the slightly enhanced XPS signal at $99.85 \mathrm{eV}$ in Figure $5 \mathrm{a}$, correspond to $\mathrm{Si}-\mathrm{C}$ bonds, and, at $282.5 \mathrm{eV}$ in Figure 5b, correspond to C-Si bonds [22], which could originate from the HMDSO precursor. The $\mathrm{Zn}$ content of the doped films determined by EDX of 2.3 at.\% at a secondary precursor flow rate of $100 \mu \mathrm{L} / \mathrm{min}$ is in good agreement with the value obtained by XPS of 1.3 at. $\%$ and decreases with a reducing flow rate, which is reflected by a reduced $\mathrm{Zn} 2 \mathrm{p}$ signal.

Figure 6 shows the XPS spectra of the $\mathrm{Cu}-\mathrm{SiO}_{\mathrm{x}}$ film grown at the highest secondary precursor flow rate of $50 \mu \mathrm{L} / \mathrm{min}$. The spectra were again separated into their individual components. In analogy to the $\mathrm{Zn}-\mathrm{SiO}_{\mathrm{x}}$ films, the peaks in the $\mathrm{Si} 2 \mathrm{p}$ spectrum in Figure 6a located at 103.5 and $101.6 \mathrm{eV}$ correspond to $\mathrm{Si}-\mathrm{O}$ and $\mathrm{Si}-\mathrm{N}$ bonds, respectively, where the Si-N bonds stem from the not fully dissipated secondary precursor. The two peak positions in the $\mathrm{O} 1 \mathrm{~s}$ spectrum in Figure $6 \mathrm{~b}$ located at 533.1 and $530.6 \mathrm{eV}$ correspond to O-Si and O-Cu bonds, which align with the Si $2 p$ and the $\mathrm{Cu} 2 \mathrm{p}$ spectra in Figure 6a,c. The differences in binding energies of $\mathrm{Cu}$ and $\mathrm{O}$ in $\mathrm{CuO}$ and $\mathrm{Cu}_{2} \mathrm{O}$ reported in Reference [23] lead to the conclusion that $\mathrm{Cu}_{2} \mathrm{O}$ is present within the $\mathrm{Cu}-\mathrm{SiO}_{\mathrm{x}}$ films. In addition, within this scenario, the absence of the $\mathrm{Si}-\mathrm{Si}$ and $\mathrm{Cu}-\mathrm{Cu}$ bonds indicates full oxidation of the film in the surface near region. This result 
is in good agreement with the findings of Maroie et al. [24]. The contamination of the $\mathrm{Cu}-\mathrm{SiO}_{\mathrm{x}}$ film by carbon-containing species is similar to the $\mathrm{Zn}-\mathrm{SiO}_{\mathrm{x}}$ films, which is indicated by the $\mathrm{C} 1 \mathrm{~s}$ spectrum in Figure $6 \mathrm{~d}$. Due to a generally lower secondary precursor flow rate during deposition of the $\mathrm{Cu}-\mathrm{SiO}_{\mathrm{x}}$ films, the $\mathrm{Cu}$ content was systematically lower with respect to the $\mathrm{Zn}$ content in the $\mathrm{Zn}-\mathrm{SiO}_{\mathrm{x}}$ films. The maximum concentration of $\mathrm{Cu}$ determined by EDX and XPS was, thus, only $\sim 0.2$ at. $\%$ at the maximum flow rate of the secondary precursor of $50 \mu \mathrm{L} / \mathrm{min}$.
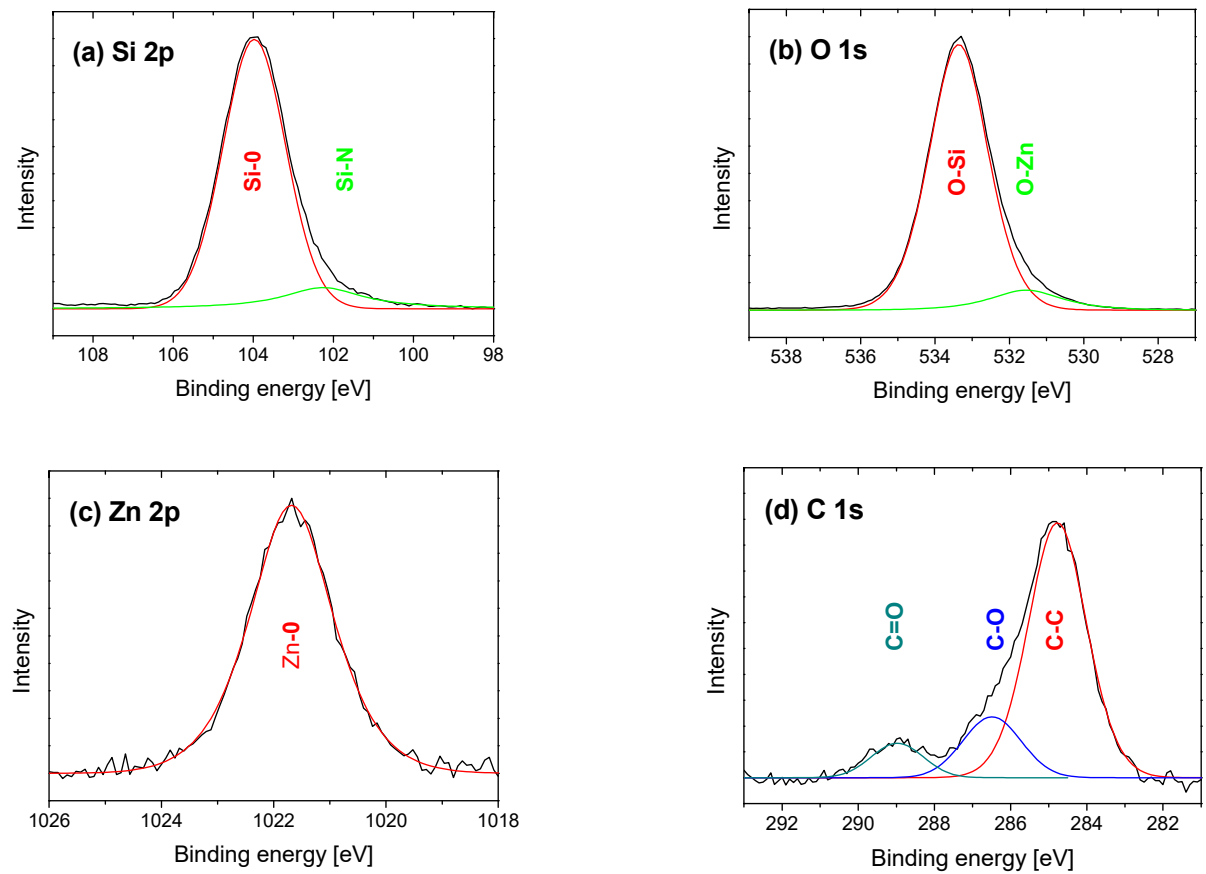

Figure 5. XPS spectra for the (a) Si 2p, (b) O 1s, (c) Zn 2p, and (d) C 1s orbitals of the $\mathrm{Zn}-\mathrm{SiO}_{\mathrm{x}}$ film grown onto $\mathrm{Si}$ with a secondary precursor flow rate of $100 \mu \mathrm{L} / \mathrm{min}$.
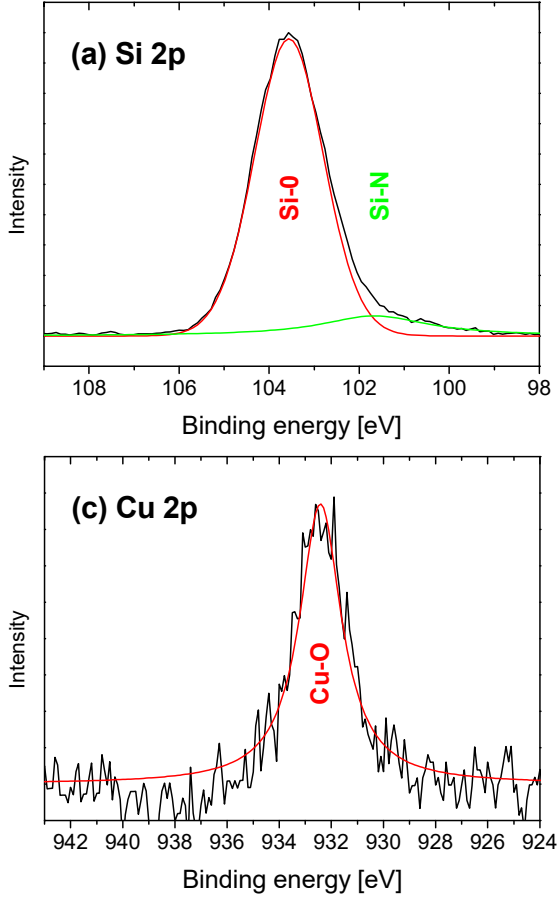


Figure 6. XPS spectra for the (a) Si 2p, (b) O 1s, (c) $\mathrm{Cu} 2 \mathrm{p}$, and (d) $\mathrm{C} 1$ s orbitals of the $\mathrm{Cu}-\mathrm{SiO}_{\mathrm{x}}$ film grown onto Si with a secondary precursor flow rate of $50 \mu \mathrm{L} / \mathrm{min}$. 


\subsection{Cytotoxic Effect}

The development of the number of cells grown on the surfaces of the un-doped $\mathrm{SiO}_{x}$ as well as $\mathrm{Zn}-\mathrm{SiO}_{\mathrm{x}}$ and $\mathrm{Cu}-\mathrm{SiO}_{\mathrm{x}}$ films during exposure to osteoblastic mouse cells of type MC 3T3-E1 characterized by the live/dead staining assay is visualized in Figure 7 for those films produced at the highest flow rates of the respective secondary precursor on austenitic stainless steel substrates. A dispersed green fluorescent cell floor (i.e., a negligible number of dead cells) indicates the spread cell formation after staining the samples post one day of incubation (Figure 7a,d,g). For comparison, the uncoated reference samples showed the same dispersed green fluorescent cell floor, which does not have a significant cytotoxic effect. The micrographs taken after one (Figure $7 \mathrm{a}, \mathrm{d}, \mathrm{g}$ ) and three days of exposure (Figure $7 \mathrm{~b}, \mathrm{e}, \mathrm{h}$ ) indicate no cytotoxic effect but a certain inhibition in cell growth, which is more pronounced for the $\mathrm{Zn}-\mathrm{SiO}_{\mathrm{x}}$ compared to the $\mathrm{Cu}-\mathrm{SiO}_{\mathrm{x}}$ film. A dramatic increase of the cell density on all film surfaces after seven days of the test results in an unhampered cell growth (see Figure 7c,f,i). After these seven days, the development of the cell growth in the case of $\mathrm{SiO}_{\mathrm{x}}$ is similar to that observed for the doped films, which shows that the addition of $\mathrm{Zn}$ and $\mathrm{Cu}$ does not disturb cell growth.
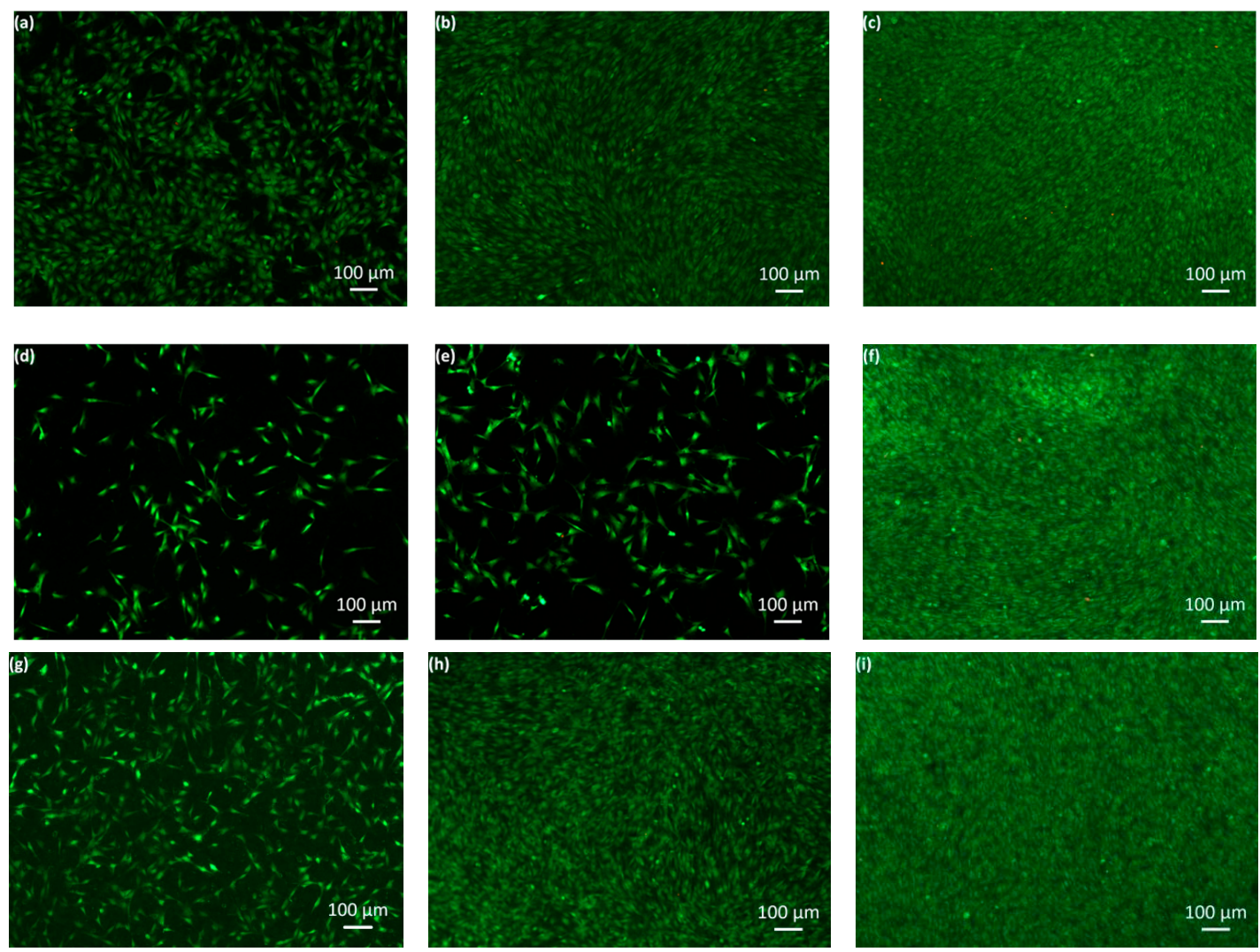

Figure 7. Representative live/dead staining images for austenitic stainless steel disks coated with $(\mathbf{a}-\mathbf{c})$ an un-doped $\mathrm{SiO}_{\mathbf{x}}$ film, (d-f) a $\mathrm{Zn}-\mathrm{SiO}_{\mathbf{x}}$ film grown at a secondary precursor flow rate of $100 \mu \mathrm{L} / \mathrm{min}$, and $(\mathbf{g}-\mathbf{i})$ a $\mathrm{Cu}_{-} \mathrm{SiO}_{\mathbf{x}}$ film grown at $50 \mu \mathrm{L} / \mathrm{min}$ on the first $(\mathbf{a}, \mathbf{d}, \mathbf{g})$, third $(\mathbf{b}, \mathbf{e}, \mathbf{h})$, and seventh evaluation day $(\mathbf{c}, \mathbf{f}, \mathbf{i})$.

\subsection{Antibacterial Activity}

Figure 8a shows the antibacterial activity of the $\mathrm{Zn}-\mathrm{SiO}_{\mathrm{x}}$ films, expressed by the luminescence of ATP with respect to the uncoated reference austenitic stainless steel and TiAl6V4 samples for an increasing secondary precursor flow rate. In an earlier study, no significant antibacterial effect of the un-doped $\mathrm{SiO}_{\mathrm{x}}$ film, as expressed by the luminescence of ATP, was determined [17]. A significant decrease of luminescence is visible for the increasing $\mathrm{Zn}\left(\mathrm{NO}_{3}\right)_{2}$ flow rate, where a flow rate of $25 \mu \mathrm{L} / \mathrm{min}$ was sufficient for an unambiguous antibacterial activity. Compared to $\mathrm{Zn}-\mathrm{SiO}$, the $\mathrm{Cu}-\mathrm{SiO} \mathrm{x}_{\mathrm{x}}$ 
system showed a considerably more pronounced antibacterial effect (see Figure 8b), irrespective of the film composition and the used substrate, even for the reduced $\mathrm{Cu}\left(\mathrm{NO}_{3}\right)_{2}$ concentration of $2.5 \mathrm{wt}$.\% obtained for the secondary precursor flow rate of $50 \mu \mathrm{L} / \mathrm{min}$. The luminescence of ATP decreased to $1 \%$ for all flow rates investigated. Thus, it can be concluded that an antibacterial effect is evident for $\mathrm{Cu}-\mathrm{SiO}_{\mathrm{x}}$ films grown with a much lower secondary precursor flow ratio compared to the $\mathrm{Zn}-\mathrm{SiO}$ films (see Section 3.1 and compare Figure 8a,b).
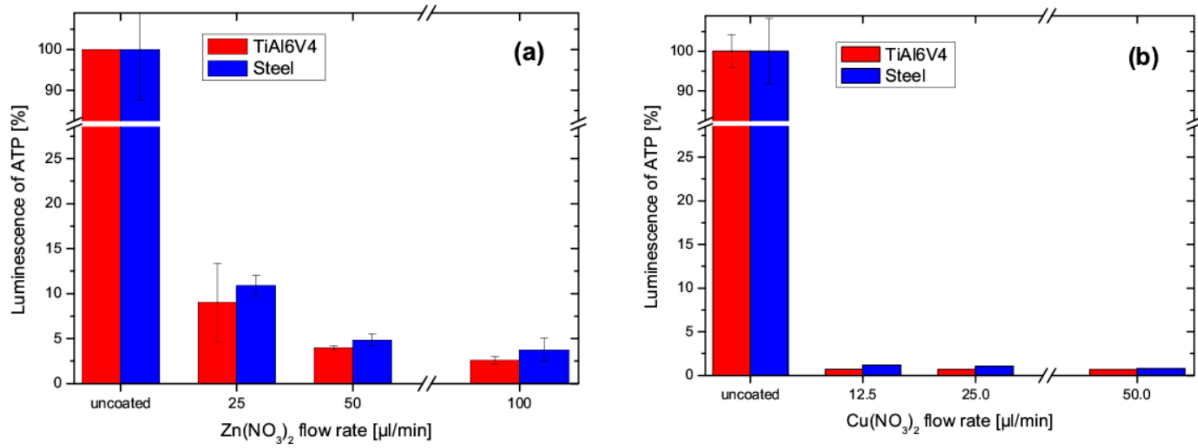

Figure 8. Influence of the flow rate used for (a) $\mathrm{Zn}-\mathrm{SiO}_{\mathrm{x}}$ films grown with a secondary precursor concentration of $5 \mathrm{wt} . \% \mathrm{Zn}\left(\mathrm{NO}_{3}\right)_{2}$ and (b) $\mathrm{Cu}-\mathrm{SiO}_{\mathrm{x}}$ films grown with a secondary precursor concentration of $2.5 \mathrm{wt} . \% \mathrm{Cu}\left(\mathrm{NO}_{3}\right)_{2}$ on detectable luminescence of ATP compared to uncoated austenitic stainless steel and TiAl6V4 reference samples.

Degradation of the film surface during the washability test results in a modification of the film and substrate surface topography, as shown in Figure 9 for the $\mathrm{Zn}-\mathrm{SiO}_{\mathrm{x}}$ film in the as-deposited state and after 1000 washing cycles. After these washing cycles, the film surface appears smoother $\left(R_{a}=500 \mathrm{~nm}\right.$, compare Figure $\left.9 \mathrm{~b}\right)$ than the pristine reference film sample $\left(\mathrm{R}_{\mathrm{a}}=1120 \mathrm{~nm}\right.$, compare Figure 9a). Most of the micron-sized $\mathrm{ZnO}_{x}$ and $\mathrm{CuO}_{x}$ particles and agglomerates formed on the film surface during the APCVD process were scrubbed from the surface during the washing procedure (as shown in Figure $9 \mathrm{~b}$ by the significant reduction of the particle number), which reduces the fraction of antibacterial agents on the surface (the highest Zn concentration was detected in the particles, see Figure 2). In good agreement with this finding, for both the $\mathrm{Zn}-\mathrm{SiO}_{\mathrm{x}}$ and the $\mathrm{Cu}-\mathrm{SiO}$ film, the content of $\mathrm{Zn}$ and $\mathrm{Cu}$ after 1000 washing cycles was close to the detection limit of EDX, which prevents providing reliable numbers for the loss of these antibacterial agents. However, it should be noted that another contribution to the surface smoothening observed during the washing procedure is provided by plastic surface deformation of the substrate material, as indicated by large flattened areas appearing bright in Figure 9b.
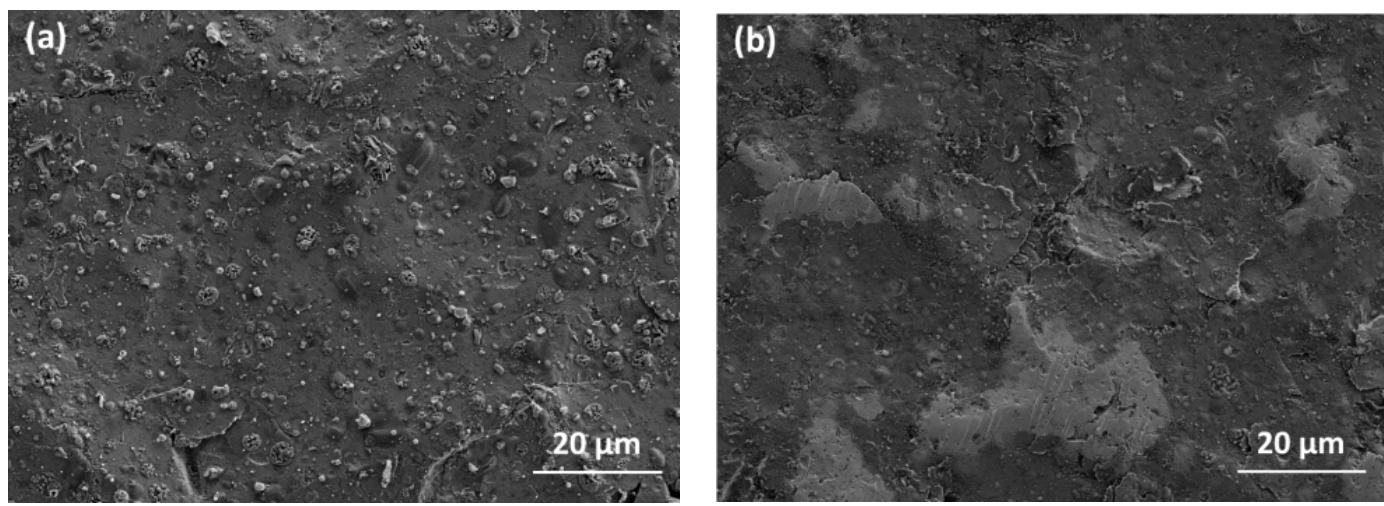

Figure 9. SEM micrographs of the surface of a $\mathrm{Zn}-\mathrm{SiO}_{\mathrm{x}}$ coated austenitic stainless steel surface (secondary precursor concentration of $5 \mathrm{wt} . \% \mathrm{Zn}\left(\mathrm{NO}_{3}\right)_{2}$, flow rate of $100 \mu \mathrm{L} / \mathrm{min}$ ). (a) As-deposited state and (b) after 1000 washing cycles. 
The mechanical loads imposed to the film surface during the washability test affect their antibacterial ability. Figure 10a indicates a strong increase in the luminescence signals of ATP for the $\mathrm{Zn}-\mathrm{SiO}_{\mathrm{x}}$ samples coated with secondary precursor flow rates of 25 and $50 \mu \mathrm{L} / \mathrm{min} \mathrm{Zn}\left(\mathrm{NO}_{3}\right)_{2}$ after 1000 washing cycles compared to the pristine film surfaces, which reach higher values and, thus, reduced or even nearly lost antibacterial ability (compare Figures $8 \mathrm{a}$ and 10a). However, for the highest precursor flow rate, an even more pronounced antibacterial ability compared to the pristine surface condition was obtained, which is most probably related to exposure of additional fresh $\mathrm{ZnO}_{\mathrm{x}}$ nanoparticles, originally hidden within the $\mathrm{SiO}_{\mathrm{x}}$ matrix, by the washing procedure.


Figure 10. Influence of the flow rate used for (a) $\mathrm{Zn}-\mathrm{SiO}_{\mathrm{x}}$ films grown with a secondary precursor concentration of 5 wt. $\% \mathrm{Zn}\left(\mathrm{NO}_{3}\right)_{2}$ and (b) $\mathrm{Cu}-\mathrm{SiO}_{\mathrm{x}}$ films grown with a secondary precursor concentration of $2.5 \mathrm{wt} . \% \mathrm{Cu}\left(\mathrm{NO}_{3}\right)_{2}$ on detectable luminescence of ATP after 1000 washing cycles. Uncoated austenitic stainless steel and TiAl6V4 samples are included as references.

The luminescence of ATP of the surface of the $\mathrm{Cu}-\mathrm{SiO}_{x}$ films after 1000 washing cycles is presented in Figure $10 \mathrm{~b}$. It reaches higher values than those of the pristine film surfaces (compare Figures $8 \mathrm{a}$ and $8 \mathrm{~b}$ ), which is most pronounced for the film with the lowest $\mathrm{Cu}$ fraction. With an increasing secondary precursor flow ratio, the difference in the antibacterial ability observed for the pristine surface and for the surface after 1000 washing cycles decreases. After further increasing the number of washing cycles up to 10,000, no reliable antibacterial effect could be detected anymore for both the $\mathrm{Zn}$-doped and Cu-doped films.

During sterilization, the film surface is exposed to heat, pressure, and chemicals like ethanol, which can be assumed to affect its antibacterial ability. The effect of the sterilization process on the antibacterial behavior of both the $\mathrm{Zn}-\mathrm{SiO}_{\mathrm{x}}$ and the $\mathrm{Cu}-\mathrm{SiO}_{\mathrm{x}}$ films deposited using secondary precursor flow rates of 100 and $50 \mu \mathrm{L} / \mathrm{min}$, respectively, is summarized in Figure 11. In both cases, the luminescence of ATP after 15 and 30 sterilization cycles increases significantly when compared to the pristine film. This increase is more severe for the $\mathrm{Cu}-\mathrm{SiO}_{\mathrm{x}}$ than for the $\mathrm{Zn}-\mathrm{SiO}$ films, and more pronounced for the austenitic stainless steel than for the TiAl6V4 substrates.
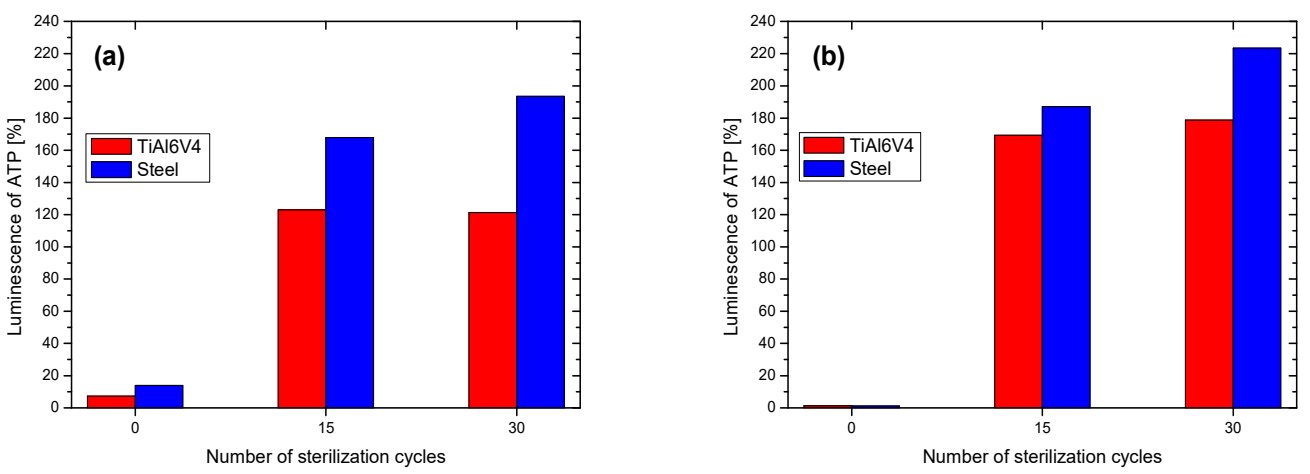

Figure 11. Luminescence of ATP of (a) $\mathrm{Zn}-\mathrm{SiO}_{\mathrm{x}}\left(\mathrm{Zn}\left(\mathrm{NO}_{3}\right)_{2}\right.$ flow rate of $\left.100 \mu \mathrm{L} / \mathrm{min}\right)$ and $(\mathbf{b}) \mathrm{Cu}-\mathrm{SiO}_{\mathrm{x}}$ films $\left(\mathrm{Cu}\left(\mathrm{NO}_{3}\right)_{2}\right.$ flow rate of $\left.50 \mu \mathrm{L} / \mathrm{min}\right)$ after 0,15 , and 30 sterilization cycles. 


\section{Discussion}

Ag-doped $\mathrm{SiO}_{\mathrm{x}}$ was demonstrated earlier to be a promising candidate for antibacterial films for medical applications [6,17]. Alternatively, antiseptic metals like $\mathrm{Zn}$ or $\mathrm{Cu}$, which are present as essential trace elements in the human body, could reduce the risks of undesired reactions when applied to the surfaces of medical implants or surgical instruments. According to the present knowledge, contact killing with $\mathrm{Cu}$ ions is assumed to proceed by successive cell membrane damage, $\mathrm{Cu}$ influx into the cells, oxidative damage, cell death, and degradation of the deoxyribonucleic acid [25]. Zn ions are potential inhibitors of catabolism and $\mathrm{O}_{2}$ metabolism. They inhibit hydrogen peroxide production nearly completely, but also enhance killing by peroxide added to the cells $[26,27]$.

The $\mathrm{Zn}-\mathrm{SiO}_{\mathrm{x}}$ and $\mathrm{Cu}-\mathrm{SiO}_{\mathrm{x}}$ films synthesized by APCVD within this research study exhibit a high density of particles on the surface, which is related to the deposition process [17]. These particles and agglomerates with sizes up to several microns are rich in $\mathrm{Zn}$ or $\mathrm{Cu}$, respectively, and their chemical state corresponds to $\mathrm{ZnO}$ or $\mathrm{Cu}_{2} \mathrm{O}$. Next to the $\mathrm{SiO}_{x}$ matrix, they represent the dominating part of the film, especially on top of the film surface (see Figures 1-3). A higher secondary precursor flow rate leads to a higher particle size and density, which correlates well with a higher $\mathrm{Cu}$ and $\mathrm{Zn}$ fraction on the film surface. The principal formation of such large particles in the gas phase is related to the kinetics of particle condensation/nucleation and growth, which is not balanced by high mass transport rates during the deposition process, and was also found for adding $\mathrm{Ag}$ particles to an $\mathrm{SiO}_{x}$ film grown by APCVD [17].

Osteoblastic mouse cells of type MC 3T3-E1 grow well on both $\mathrm{Zn}$-doped and $\mathrm{Cu}$-doped $\mathrm{SiO}_{\mathrm{x}}$ films with a slight inhibition effect present only after the first day of exposure and limited inhibition or no inhibition later (see Figure 7). Thus, no cytotoxic effect was observed. This behavior is independent of the applied secondary precursor flow rates and substrates. The slight inhibition of cell growth might be related to the pronounced release of the antiseptic $\mathrm{Zn}$ or $\mathrm{Cu}$ ions or even metal oxide nanoparticles, respectively, from the pristine film surface, which results in high efficiency for reducing bacteria, but also affects the growth of osteoblastic cells. Later-on, the film surface can be assumed to be shielded by dead cells, which suppresses the release of antiseptic ions and consequently promotes cell growth. The more pronounced inhibition of cell growth observed for the $\mathrm{Zn}-\mathrm{SiO}_{\mathrm{x}}$ compared to the $\mathrm{Cu}-\mathrm{SiO}_{\mathrm{x}}$ film is most probably related to the significantly higher $\mathrm{Zn}$ content of up to $\sim 2.3$ at. $\%$ compared to $\sim 0.2$ at.\% $\mathrm{Cu}$ derived for the highest secondary precursor flow rates. A similar effect was also observed in experiments with $\mathrm{Ag}[8,28]$.

While E. coli bacteria are exposed to the film surface, they are in direct contact with metal ions released in a humid environment or with oxide nanoparticles. The $\mathrm{Cu}$-doped films showed a more pronounced antibacterial effect compared to $\mathrm{Zn}-\mathrm{SiO}_{\mathrm{x}}$, despite the lower $\mathrm{Cu}$ concentration within the films, given by the lower secondary precursor concentration and flow rates used during film deposition (see Table 1). This might be attributed to the significantly lower ionization energy of $\mathrm{Cu}(7.7264 \mathrm{eV})$ compared to $\mathrm{Zn}(9.3941 \mathrm{eV})$, which results in a more pronounced release of $\mathrm{Cu}$ ions. For comparison, the ionization energy of $\mathrm{Ag}(7.5762 \mathrm{eV})$ is even slightly lower than that of $\mathrm{Cu}$, which results in its superior antibacterial efficiency [29]. The antibacterial efficiency of $\mathrm{Zn}$ in the E. coli suspension used in this study can be assumed to be lower than in dry environments, due its cell drying properties. Another explanation of the antibacterial ability of the films could be based on the contact to metal oxide nanoparticles, which is present in the films investigated within this study. In particular, $\mathrm{CuO}$ nanoparticles have been reported to display the highest potency in causing cell death when compared to other metal oxides like $\mathrm{TiO}_{2}, \mathrm{ZnO}, \mathrm{Fe}_{3} \mathrm{O}_{3}$, or $\mathrm{Fe}_{2} \mathrm{O}_{3}$ [30].

The washability test leads to a significant change of the surface topography of the films, since a major fraction of the $\mathrm{ZnO}_{\mathrm{x}}$ and $\mathrm{CuO}_{\mathrm{x}}$ particles have been mechanically removed after 1000 washing cycles. Beier et al. reported that, during the first ten washing cycles, a high loss of antiseptic Ag from the film surface was observed. After this burst effect, only a slightly further decreasing fraction of released Ag was found in up to 10,000 washing cycles [17]. Taking into account that most of the micron-sized $\mathrm{ZnO}_{x}$ and $\mathrm{CuO}_{x}$ particles are scrubbed from the surface after 1000 washing cycles (see Figure 9), the concentration of $\mathrm{Cu}$ and $\mathrm{Zn}$, respectively, has to be assumed to decrease dramatically in 
the same manner like in the Ag particles stated above. Nevertheless, the fraction of metal ions or metal oxide nanoparticles released from the film surface for the highest secondary precursor flow rates is still sufficient for reducing the population of E. coli bacteria (see Figure 10).

Beier et al. reported that no antibacterial activity of Ag-containing samples re-tested by repetitive interaction with an E. coli suspension and subsequent sterilization was found [17]. This is related to the more stringent procedure applied (exposure to E. coli, sterilization with ethanol for $1 \mathrm{~h}$, washing with distilled water and ethanol, drying), which promotes the fast depletion of ions from the film surface, compared to the washing cycles applied in this work. Another possible reason could be the sealing of the film surface by the sterilization procedure, which hinders the release of Ag ions [17]. Airey and Verran reported a decrease of the contact killing efficiency of $\mathrm{Cu}$ after the second soiling/cleaning cycle [31]. However, in a different study, Cu surfaces have been mentioned to remain active when soiled [32]. While there are ambiguous findings on the degradation of the antibacterial properties of $\mathrm{Cu}$ in the literature, the present understanding of the mechanism of contact killing leads to the conclusion that a clean surface, without significant oxide scales and free of wax or other films, easily releases the antibacterial agent and will always be active in contact killing [6,25]. The antibacterial activity has been reported to be lost for $\mathrm{Ag}$-doped $\mathrm{SiO}_{\mathrm{x}}$ films after annealing at $500{ }^{\circ} \mathrm{C}$ in ambient air. Ag, as a noble metal, was reported to be incorporated in metallic form into the $\mathrm{SiO}_{\mathrm{x}}$ matrix [6], which forms the thermally unstable silver sulfite in ambient industrial atmospheres containing sulfur. In contrast, $\mathrm{ZnO}_{\mathrm{x}}$ and $\mathrm{CuO}_{\mathrm{x}}$ should be able to survive the thermal exposure during the sterilization process. Thus, it can be concluded that the films investigated within this study are primarily degraded by soil and by washing procedures, which explains why they lost their antibacterial functionality after the performed sterilization tests (see Figure 11).

\section{Conclusions}

$\mathrm{SiO}_{\mathrm{x}}$ films with different fractions of the doping elements $\mathrm{Zn}$ and $\mathrm{Cu}$, respectively, were synthesized by atmospheric pressure plasma chemical vapor deposition and evaluated with respect to their antibacterial and cytotoxic effects. The formed films represent composites with $\mathrm{ZnO}$ and $\mathrm{Cu}_{2} \mathrm{O}$ particles, with diameters up to several microns, embedded into a $\mathrm{SiO}_{\mathrm{x}} \mathrm{matrix}$. The best antibacterial ability was obtained for the $\mathrm{Cu}$-containing film with the highest $\mathrm{Cu}$ content of 0.2 at.\%. While Gram-negative Escherichia coli bacteria exposed to the film surface are killed within three hours, mouse cell growth is inhibited only after the first day of exposure, with limited or no inhibition later. $\mathrm{Zn}$-doped $\mathrm{SiO}_{\mathrm{x}}$ films with slightly less pronounced antibacterial properties are obtained for a $\mathrm{Zn}$ concentration of 2.3 at.\%. While both $\mathrm{Zn}$-doped and $\mathrm{Cu}$-doped $\mathrm{SiO}_{\mathrm{x}}$ films are mechanically stable and survive 1000 washing cycles with only slightly affected antibacterial behavior for sufficient metal contents, the sterilization procedure using standard hospital cleaning and steam sterilization conditions results in rapid deterioration of the antibacterial efficiency. The formed composites based on a robust and bio-compatible $\mathrm{SiO}_{\mathrm{x}}$ matrix with added $\mathrm{Cu}_{2} \mathrm{O}$ and $\mathrm{ZnO}$ particles grown by the environmentally-friendly atmospheric plasma chemical vapor deposition technique represent promising candidates for antibacterial thin films meeting the requirement of multi-functional surfaces for medical implants and surgical instruments.

Author Contributions: Conceptualization, E.J., J.S. and A.P. Methodology, E.J., S.S., N.J. and O.B. Validation, E.J., J.S., A.P., S.S., O.B., R.D. and C.M. Formal analysis, E.J., J.S., A.P., R.D. and C.M. Investigation, E.J., S.S. and O.B. Resources, J.S. and A.P. Data curation, E.J., J.S., A.P., N.J. and O.J. Writing-original draft preparation, E.J. Writing—review and editing, R.D. and C.M. Visualization, E.J., R.D. and C.M. Supervision, J.S, A.P., R.D. and C.M.

Funding: This research received no external funding.

Acknowledgments: The authors gratefully acknowledge the assistance of Monika Doepel and Birgitt Beer in BTG and live/dead assays. Furthermore, we thank Martina Schweder and Michael Röder, Ralf Linke, Ronny Köcher, and Martina Goetjes for their help with SEM/EDX, XPS, AFM, and roughness measurements. The authors also thank the company Königsee Implantate $\mathrm{GmbH}$ for their support in sterilization tests.

Conflicts of Interest: The authors declare no conflict of interest. 


\section{References}

1. Diegelmann, R.F.; Evans, M.C. Wound healing: An overview of acute, fibrotic and delayed healing. Front. Biosci. 2004, 9, 283-289. [CrossRef] [PubMed]

2. Klevens, R.M.; Edwards, J.R.; Richards, C.L.; Horan, T.C.; Gaynes, R.P.; Pollock, D.A.; Cardo, D.M. Estimating health care-associated infections and deaths in U.S. hospitals, 2002. Public Health Rep. 2007, 122, 160-166. [CrossRef] [PubMed]

3. Cloutier, M.; Mantovani, D.; Rosei, F. Antibacterial coatings: Challenges, perspectives, and opportunities. Trends Biotechnol. 2015, 33, 637-653. [CrossRef]

4. Heidenau, F.; Mittelmeier, W.; Detsch, R.; Haenle, M.; Stenzel, F.; Ziegler, G.; Gollwitzer, H. A novel antibacterial titania coating: Metal ion toxicity and in vitro surface colonization. J. Mater. Sci. Mater. Med. 2005, 16, 883-888. [CrossRef] [PubMed]

5. Velasco, S.C.; Cavaleiro, A.; Carvalho, S. Functional properties of ceramic-Ag nanocomposite coatings produced by magnetron sputtering. Prog. Mater. Sci. 2016, 84, 158-191. [CrossRef]

6. Zimmermann, R.; Pfuch, A.; Horn, K.; Weisser, J.; Heft, A.; Röder, M.; Linke, R.; Schnabelrauch, M.; Schimanski, A. An approach to create silver containing antibacterial coatings by use of atmospheric pressure plasma chemical vapour deposition (APCVD) and combustion chemical vapour deposition (CCVD) in an economic way. Plasma Process. Polym. 2011, 8, 295-304. [CrossRef]

7. Stranak, V.; Wulff, H.; Rebl, H.; Zietz, C.; Arndt, K.; Bogdanowicz, R.; Nebe, B.; Bader, R.; Podbielski, A.; Hubicka, Z.; et al. Deposition of thin titanium-copper films with antimicrobial effect by advanced magnetron sputtering methods. Mater. Sci. Eng. C 2011, 31, 1512-1519. [CrossRef]

8. Ewald, A.; Glückermann, S.K.; Thull, R.; Gbureck, U. Antimicrobial titanium/silver PVD coatings on titanium. Biomed. Eng. Online 2006, 5, 22. [CrossRef] [PubMed]

9. Silva-Ichante, M.; Reyes-Vidal, Y.; Bácama-Valenzuela, F.J.; Ballesteros, J.C.; Arciga, E.; Ţălu, Ş.; Méndez-Albores, A.; Trejo, G. Electrodeposition of antibacterial Zn-Cu/silver nanoparticle (AgNP) composite coatings from an alkaline solution containing glycine and AgNPs. J. Electroanal. Chem. 2018, 823, 328-334. [CrossRef]

10. Shu, Z.; Zhang, Y.; Huaming, Y. Halloysite nanotubes supported Ag and ZnO nanoparticles with syntergistically enhanced antibacterial activity. Nanoscale Res. Lett. 2017, 12, 135. [CrossRef] [PubMed]

11. Costa, S.M.; Ferreira, D.P.; Ferreira, A.; Vaz, F.; Fangueiro, R. Multifunctional flax fibres based on the combined effect of silver and zinc oxide $(\mathrm{Ag} / \mathrm{ZnO})$ nanostructures. Nanomaterials 2018, 8, 1069. [CrossRef] [PubMed]

12. Fu, L.-H.; Gao, Q.-L.; Qi, C.; Ma, M.-G.; Li, J.-F. Microwave-hydrothermal rapid synthesis of cellulose/Ag nanocomposites and their antibacterial activity. Nanomaterials 2018, 8, 978. [CrossRef] [PubMed]

13. Diez-Pascual, A.M. Antibacterial activity of nanomaterials. Nanomaterials 2018, 8, 359. [CrossRef] [PubMed]

14. Gassner, M.; Rebelo de Figueiredo, M.; Schalk, N.; Franz, R.; Weiß, C.; Rudigier, H.; Holzschuh, H.; Bürgin, W.; Pohler, M.; Czettl, C.; et al. Energy consumption and material fluxes in hard coating deposition processes. Surf. Coat. Technol. 2016, 299, 49-55. [CrossRef]

15. Burduşel, A.-C.; Gherasim, O.; Grumuzescu, A.M.; Mogoantă, L.; Ficau, A.; Andonescu, E. Biomedical applications of silver nanoparticles: An up-to-date overview. Nanomaterials 2018, 8, 681. [CrossRef]

16. Marimbio-Jones, C.; Hoek, E.M.V. A review of the antibacterial effects of silver nanomaterials and potential implications for human health and the environment. J. Nanoparticle Res. 2010, 12, 1531-1551. [CrossRef]

17. Beier, O.; Pfuch, A.; Horn, K.; Weisser, J.; Schnabelrauch, M.; Schimanski, A. Low temperature deposition of antibacterially active silicon oxide layers containing silver nanoparticles, prepared by atmospheric pressure plasma chemical vapor deposition. Plasma Process. Polym. 2013, 10, 77-87. [CrossRef]

18. Pfuch, A.; Horn, K.; Mix, R.; Ramm, M.; Heft, A.; Schimanski, A. Direct and remote plasma assisted CVD at atmospheric pressure for the preparation of oxide thin films. Galvanotechnik 2012, 103, 814-824.

19. Abràmoff, M.D.; Magalhāes, P.J.; Ram, S.J. Image processing with ImageJ. Biophoton. Int. 2004, 11, 36-41.

20. Wagner, C.D.; Riggs, W.M.; Davis, L.E.; Moulder, J.F.; Muilenberg, G.E. Handbook of X-ray Photoelectron Spectroscopy; Physical Electronics Division, Perkin Elmer Corporation: Eden Prairie, Minnesota, MN, USA, 1979. 
21. Al-Ghaashani, R.; Radiman, S.; Daud, A.R.; Tabet, N.; Al-Douri, Y. XPS and optical studies of different morphologies of $\mathrm{ZnO}$ nanostructures prepared by microwave methods. Ceram. Int. 2013, 39, 2283-2292. [CrossRef]

22. Wang, Y.-Y.; Kusumoto, K.; Li, C.-J. XPS analysis of SiC films prepared by radio frequency plasma sputtering. Phys. Proc. 2012, 32, 95-102. [CrossRef]

23. Barreca, D.; Gasparotto, A.; Tondello, E. CVD $\mathrm{Cu}_{2} \mathrm{O}$ and $\mathrm{CuO}$ nanosystems characterized by XPS. Surf. Sci. Spectra 2007, 14, 41-51. [CrossRef]

24. Maroie, S.; Haemers, G.; Verbist, J.J. Surface oxidation of polycrystalline $\alpha(75 \% \mathrm{Cu} / 25 \% \mathrm{Zn})$ and $\beta(53 \% \mathrm{Cu} / 47 \% \mathrm{Zn})$ brass as studied by XPS: Influence of oxygen pressure. Appl. Surf. Sci. 1984, 17, 463-467. [CrossRef]

25. Grass, G.; Rensing, C.; Solioz, M. Metallic copper as an antimicrobial surface. Appl. Environ. Microb. 2011, 77, 1541-1547. [CrossRef]

26. Sheng, J.; Nguyen, P.T.M.; Marquis, R.E. Multi-target antimicrobial actions of zinc against oral anaerobes. Arch. Oral Biol. 2005, 50, 747-757. [CrossRef] [PubMed]

27. Sawai, J. Quantitative evaluation of antibacterial activities of metallic oxide powders $(\mathrm{ZnO}, \mathrm{MgO}$ and $\mathrm{CaO})$ by conductimetric assay. J. Microbiol. Meth. 2003, 54, 177-182. [CrossRef]

28. Khalilpour, P.; Lampe, K.; Wagener, M.; Stigler, B.; Heiss, C.; Ulrich, M.S.; Domann, E.; Schnettler, R.; Alt, V. $\mathrm{Ag} / \mathrm{SiO}_{\mathrm{x}} \mathrm{C}_{\mathrm{y}}$ plasma polymer coating for antimicrobial protection of fracture fixation devices. J. Biomed. Mater. Res. B 2010, 94, 196-202. [CrossRef]

29. Malachová, K.; Praus, P.; Rybuková, Z.; Kozák, O. Antibacterial and antifungal activities of silver, copper and zinc montmorrillinites. Appl. Clay Sci. 2011, 53, 642-645. [CrossRef]

30. Karlsson, H.L.; Toprak, M.S.; Fadeel, B. Toxicity of metal and metal oxide nanoparticles. In Handbook on the Toxicology of Metals, 4th ed.; Nordberg, G.F., Fowler, B.A., Nordberg, M., Eds.; Elsevier/Academic Press: London, UK, 2015; pp. 75-112.

31. Airey, P.; Verran, J. Potential use of copper as a hygienic surface; problems associated with cumulative soiling and cleaning. J. Hosp. Infect. 2007, 67, 271-277. [CrossRef]

32. Wheeldon, L.J.; Worthington, T.; Lambert, P.A.; Hilton, A.C.; Lowden, C.J.; Elliott, T.S.J. Antimicrobial efficacy of copper surfaces against spores and vegetative cells of Clostridium difficile: The germination theory. J. Antimicrob. Chemoth. 2008, 62, 522-525. [CrossRef] 